\title{
Environmental Profile of Building Materials of a Single Family House
}

\author{
Milan Porhinčák \\ Technical University of Košice, Civil \\ Engineering Faculty, Institute of \\ Environmental Engineering, Slovakia \\ milan.porhincak@tuke.sk
}

\author{
Adriana Eštoková \\ Technical University of Košice, Civil \\ Engineering Faculty, Institute of \\ Environmental Engineering, Slovakia \\ adriana.estokova@tuke.sk
}

DOI 10.5592/otmcj.2011.2.7

Research paper

\section{Keywords}

Building materials, environmental assessment, energy consumption, global warming, acidification

\section{INTRODUCTION}

In highly developed countries the tendencies leading to minimization of operational energy (energy required for heating, cooling, lighting etc.) are currently being fulfilled. Application of state-of-art appliances, equipment or technologies, such as heat pumps, solar collectors or photovoltaic cells together with improvements of constructional design, such as application of high high-class insulating windows, thermal insulation or air barriers resulted in maximal efficiency and minimization of energy inputs and reduction of $\mathrm{CO}_{2}$ and $\mathrm{SO}_{2}$ emissions.

In these days' very popular passive houses amount of energy required for operation of building together with 
amount of emissions are minimized in the highest possible way, and therefore there further reduction is not effective. However, when taking the whole life of building into consideration with all phases of buildings life cycle, the situation is different. As stated by Vonka (2010), in conventional building from recent era the ratio of energy embodied in building materials and operational energy required for heating of building (80 years period) is approximately 1:15, therefore optimization and improvement is usually aimed at phase of operation. Estimated ratio of embodied and operational energy is even higher in older buildings (from 1920s) and exceeds 1:25. In contrast, in progressive houses, where usually large amounts of various modern buildings materials are used, the ratio of embodied energy and operational energy is several times lower (approx. 1:4). Whereas, in modern low-energy and passive houses the operational stage is almost fully optimized, another improvement with aim of reaching the goals of sustainability has to be oriented on rigorous selection of building materials with minimal possible negative influence on environment.

Research in branch of civil engineering, material and environmental engineering should be focused on looking for materials to provide at least the same or even better standard and to ensure better environmental quality and sustainability, as proved by Khasreen et al. (2009). Important factor is to assure minimization of depletion of natural non-renewable resources, maximizing of reusing or recycling, reduction of greenhouse gasses emissions or reduction of waste creation. It is important to create the relevant database of building material, where besides conventional criteria (technical properties or price) also environmental criteria will be included (Hodkova, 2009). However, environmental assessment is still only additional type of evaluation of proper- ties; however it is also the matter of the time, when environmental criteria will be incorporated into conventional assessment and certification of building materials.

This paper is aimed at analyzing of the building materials of a single-family house from environmental point of view on the basis of life cycle assessment. Evaluation included the amount of used material, the global warming potential, the acidification potential and primary energy intensity related to the particular structures as well as the whole building.

\section{Environmental assessment of building}

\section{Description of assessed building}

A single family masonry house designed by Tomkova (2009) was selected to illustrate the environmental profile of building in terms of used materials. Building is without basement with ground floor and inhabited loft, what correspondents to contemporary mostly preferred type of individual masonry build up in Slovak republic. Daytime area of house is situated in the first floor (ground floor) and consists of kitchen, living room, office, bathroom and boiler room. In the second floor, there is bathroom, toilet, clothes room and 3 bedrooms. Object is well suited for accommodation of 3 to 5 people. Areas of house are described in table 1.

\begin{tabular}{|l|c|}
\hline Built up area & $96.8 \mathrm{~m}^{2}$ \\
\hline Useful area & $138.6 \mathrm{~m}^{2}$ \\
\hline Floorage (living area) & $79.6 \mathrm{~m}^{2}$ \\
\hline Total capacity & $667.9 \mathrm{~m}^{3}$ \\
\hline
\end{tabular}

Table 1: Area and capacity of assessed family house

\section{Building materials used for structures}

Assessed family house represents a wide-spread type of individual Slovak build up (fig. 1). Foundation strips as well as base plate are made of plain concrete. A certain amount of gravel is used in the underwork as draining. Load bearing external and internal walls are designed of aerated concrete blocks with thickness of 375 and $250 \mathrm{~mm}$. Partitioning walls are also made of $150 \mathrm{~mm}$ thick aerated concrete blocks. Horizontal load bearing structures (ceiling, bond-beams) together with staircase are produced from reinforced concrete. Framework of gabled roof is made of air-dried and technically dried wood. Roofs weatherproofing is secured by concrete roof tiles. Lime-cement plasters are used to create inner as well as outer surface. Ceramic tiles are also used in walls of toilet and bathroom. Flooring surfaces are designed of ceramic and concrete flooring tiles and wood flooring panels. Damp proof course is secured by bitumen coating. Façade is not insulated. However, thermal insulation is used to eliminate heat bridges. Mineral wool is used in the roof and foam glass is used in the underwork. Windows and doors are designed of wooden euro-profiles with triple insulating glass.

\section{Methodology}

Life Cycle Assessment is one of the most complex methods available for environmental assessment of any human activity and can be applied for evaluation of environmental impact of building materials, components or whole building. In this study a tool based on LCA database of IBO Institute (Waltjen, 2009) of environmental properties of building materials was used to illustrate environmental profile of building materials built-in the finished building. Parameters, such as amount of used materials, Primary Energy Intensity (PEI), Global Warming Potential (GWP) and Acidification 

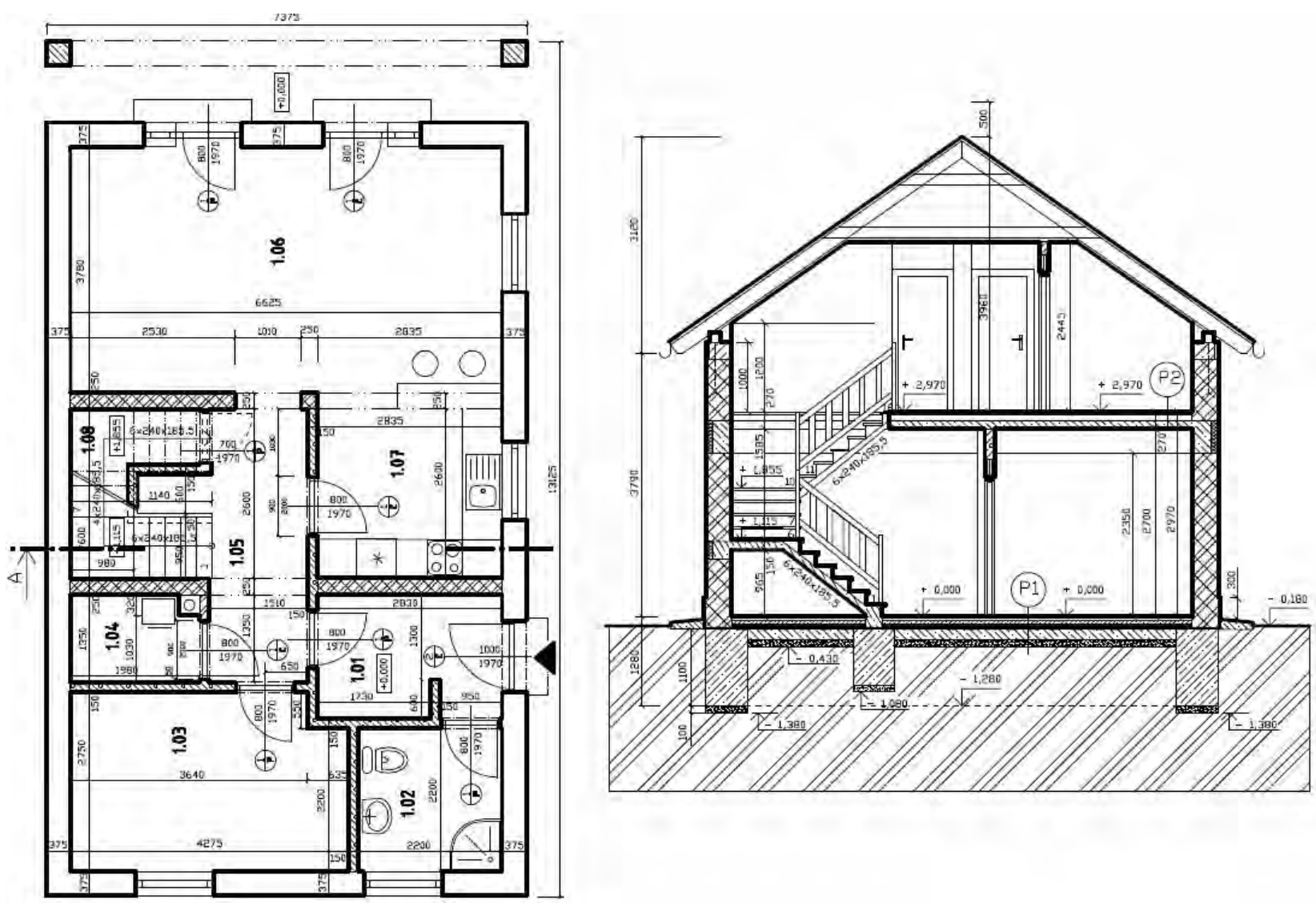

Figure 1: Simple drawing of assessed house

Potential (AP) were evaluated. Building materials were divided into 10 groups of structures (components combinations), upon Kierulf (2008). Volumes and areas of used materials were used as input values.

Primary energy intensity (primary energy input, embodied energy) indicates the level of depletion of natural resources (Estokova, 2008). This value in MJ/ $\mathrm{kg}$ or $\mathrm{kWh} / \mathrm{t}$ indicates the total energy required for every phase within boundaries of life cycle. Amount of primary energy from non-renewable sources is assessed in this paper. Global warming potential results from various anthropogenic processes, e.g. combustion of fossil fuels above all. The strength of global warming potential is calculated by amount of greenhouse gases emissions $\left(\mathrm{CO}_{2}, \mathrm{CH}_{4} \mathrm{~N}_{2} \mathrm{O}\right.$ etc. $)$ which is expressed by $\mathrm{kg}$ of $\mathrm{CO}_{2}$ eq; however there is a wide range of other substances, such as water vapor, $\mathrm{CH}_{4}$ or $\mathrm{N}_{2} \mathrm{O}$ to contribute to global warming. Acidification potential demon- strates contribution to decreasing of $\mathrm{pH}$. Amount of $\mathrm{SO}_{2}$ emissions is the major factor which participates in acidification; however there is wide range of substances which participate in decreasing of $\mathrm{pH}$ of environment. Weight of $\mathrm{SO}_{2}$ eq emissions is used for expression of the overall acidification potential.

\section{Results}

\section{Overall assessment}

The results of environmental assessment of selected building in terms of used materials are presented in table 2. Data include volume of used materials, amount of embodied energy, quantity of embodied $\mathrm{CO}_{2}$ emissions and $\mathrm{SO}_{2}$ emissions.

\begin{tabular}{|c|c|c|c|}
\hline Volume $\left(\mathrm{m}^{3}\right)$ & PEI $(\mathrm{MJ})$ & $\mathrm{GWP}(\mathrm{kg} \mathrm{CO}$ eq $)$ & $\mathrm{AP} \mathrm{kg}\left(\mathrm{SO}_{2}\right.$ eq $)$ \\
\hline 208.1 & 441394.3 & 34953.6 & 129.9 \\
\hline
\end{tabular}

Table 2: Results of overall environmental assessment of building 


\begin{tabular}{|l|c|c|c|}
\hline & PEI $\left(\mathrm{MJ} / \mathrm{m}^{2}\right)$ & $\begin{array}{c}\mathrm{GWP} \\
\left(\mathrm{kg} \mathrm{CO}_{2} \mathrm{eq} / \mathrm{m}^{2}\right)\end{array}$ & $\begin{array}{c}\mathrm{AP} \\
(\mathrm{kg} \mathrm{SO}\end{array}$ \\
\hline Per build up area & 4559.86 & 361.09 & 1.3421 \\
\hline Per useful area & 3184.66 & 252.19 & 0.9374 \\
\hline Per floorage (living area) & 5545.15 & 439.12 & 1.6321 \\
\hline & PEI $\left(\mathrm{MJ} / \mathrm{m}^{3}\right)$ & $\begin{array}{c}\mathrm{GWP} \\
\left(\mathrm{kg} \mathrm{CO}_{2} \mathrm{eq} / \mathrm{m}^{3}\right)\end{array}$ & $\begin{array}{c}\mathrm{AP} \\
\left(\mathrm{kg} \mathrm{SO} \mathrm{eq} / \mathrm{m}^{3}\right)\end{array}$ \\
\hline Total capacity & 660.88 & 52.33 & 0.1945 \\
\hline
\end{tabular}

Group with highest share of embodied energy is represented by concrete materials (32\%), which results from relatively high amount of their utilization for the construction of components, such as foundation, bond beams, ceilings, etc. Material with the second highest amount of primary energy intensity rated at $\mathbf{2 2} \%$ is aerated concrete and the third highest energy

Table 3: Normalized values of environmental assessment

\section{Assessment of groups of building material}

It is important to have knowledge of material basis and their amount. This is useful for further comparison of similar buildings and for potential optimization of material composition aimed at minimization of negative environmental impact. Percentage of particular material groups used in the assessed object is illustrated in fig. 2; primary energy intensity of particular materials is in fig. 3. Contribution to global warming is presented in fig. 4 and acidification potential is displayed in fig. 5 .

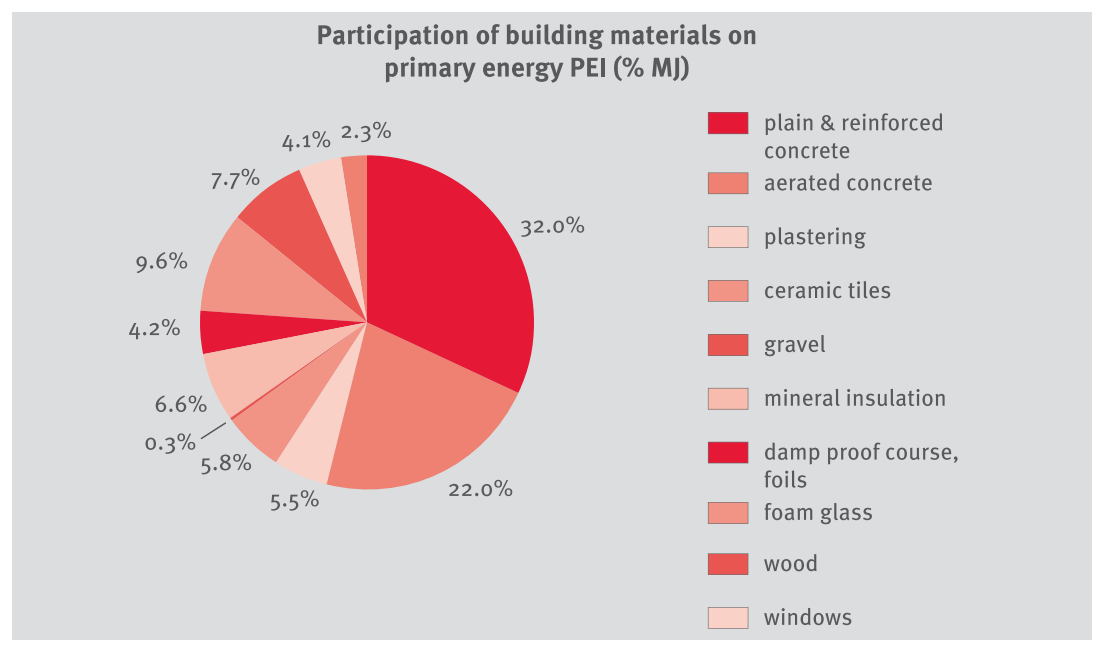

Figure 3: Participation of building materials on primary energy PEI (\% MJ))

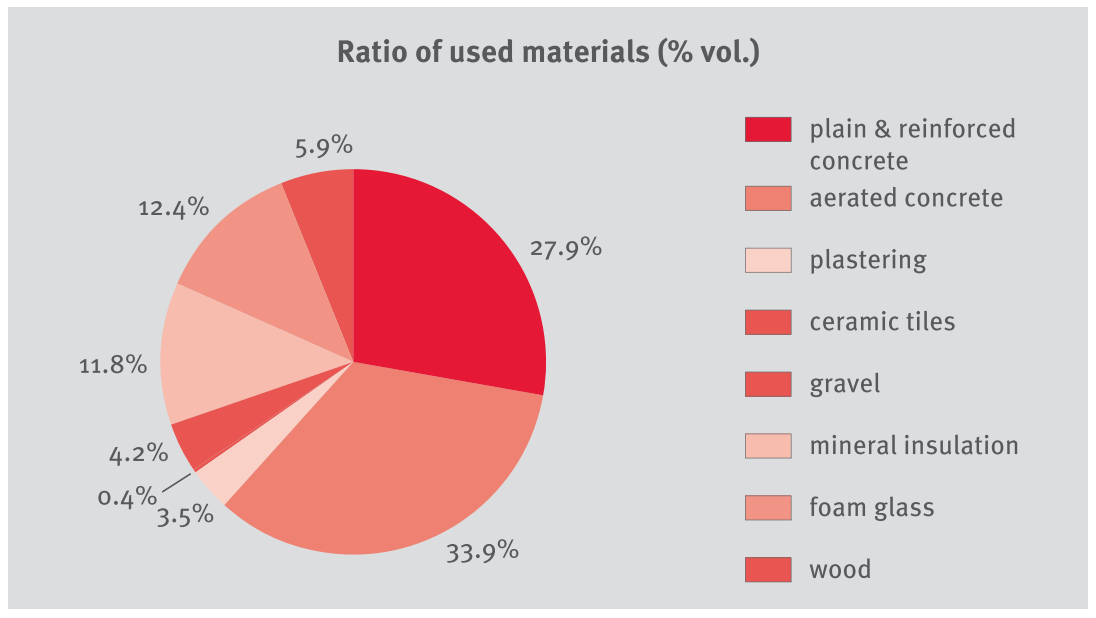

Figure 2: Ratio of used materials (\% vol.)

As illustrated in fig. 2 and as expected, the material with highest volume percentage is plain and reinforced concrete $(33.9 \%)$. Fairly high mass is covered by a material of vertical constructions - walls made of aerated concrete blocks (29.7\%). High volume was also calculated for materials of thermal in- sulation (foam glass $-12.4 \%$ and mineral insulation - $11.8 \%$ ).

A contribution of particular groups of materials to consumption of primary energy is expressed by their percentage from amount total embodied energy of the whole family house. Results are presented in fig. 3 . intensive material used for building constructions is foam glass.

Ratio of contribution of particular material groups to global warming is illustrated in fig. 4 .

The highest participation on global warming $(42.7 \%)$ was calculated for group of concrete and reinforced concrete followed by aerated concrete (22.3 $\%)$ as it is seen in fig. 4. An interesting fact is, that a negative contribution to global warming potential was recorded at wood materials $(-8.3 \%)$ due to their ability of storing carbon dioxide in their structure while their growth. It is possible to reach the negative $\mathrm{CO}_{2}$ emissions by a wide-spread use of building materials on natural basis, e.g. wood, flax, hemp etc. When considering the life cycle of building materials without the last stage of its existence, when the material could be combusted or composted the $\mathrm{CO}_{2}$ remains stored in the mate- 


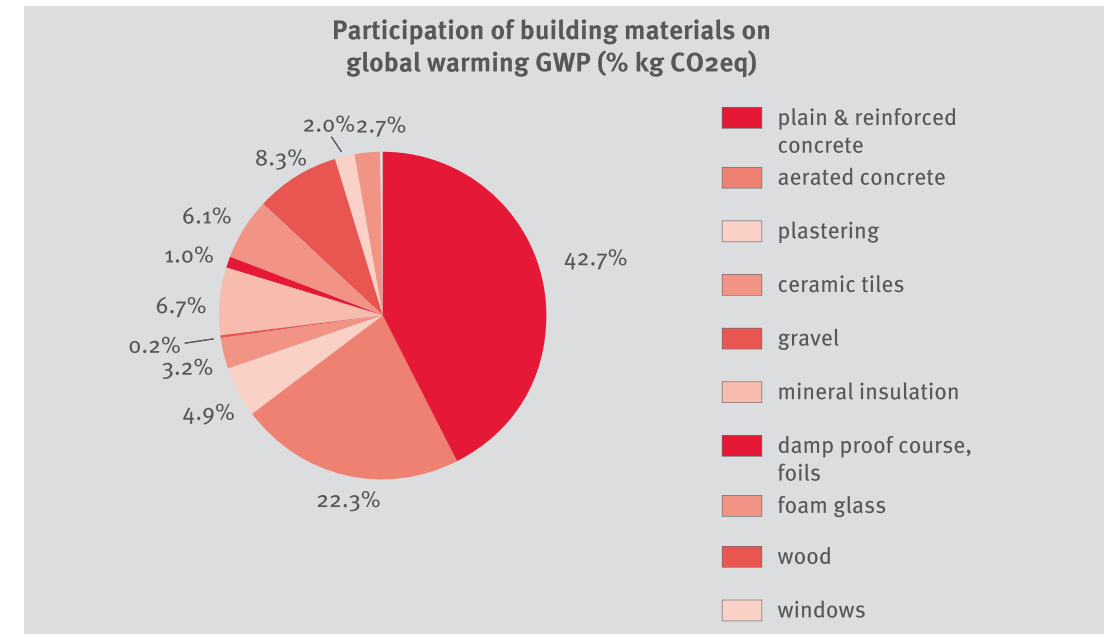

Figure 4: Participation of building materials on global warming GWP (\% kg CO2eq)

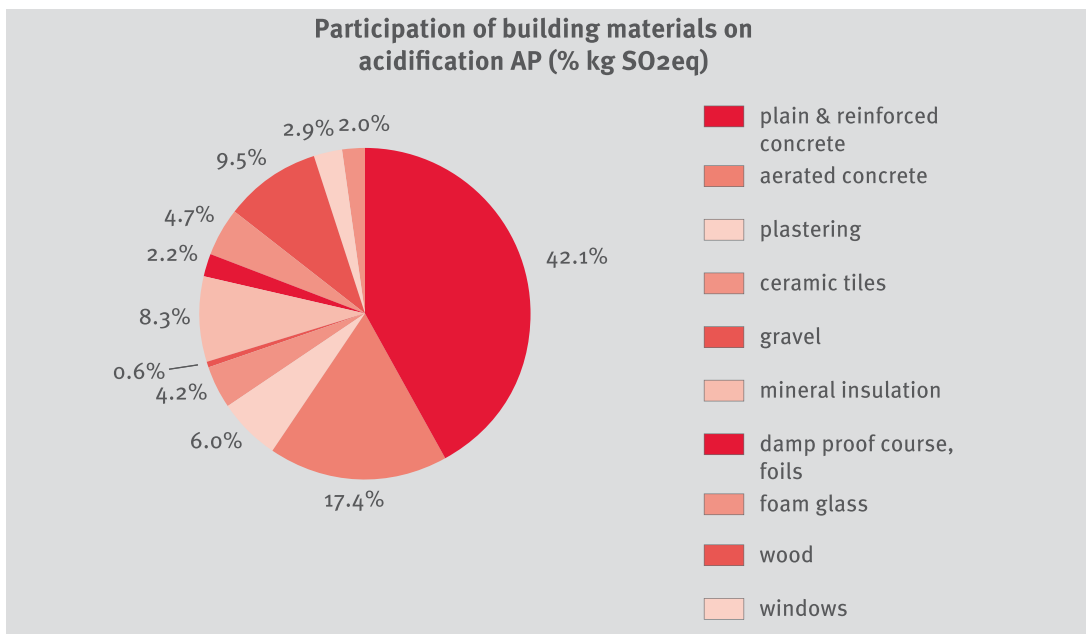

Figure 5: Participation of building materials on acidification potential AP (\% kg SOzeq)

rial structure and no greenhouse gasses emissions are taken into consideration (Berge, 2009; Waltjen, 2009).

Effect of acidification impact of evaluated building materials is illustrated in fig. 5 .

The highest contribution to acidification $(42.1 \%)$ was calculated again for the concrete structures (plain and reinforced concrete). High $\mathrm{SO}_{2}$ emissions were also recorded for aerated concrete (17.4\%) and wood materials (9.5\%).

\section{Assessment of building materials in structures}

Environmental evaluation was also performed in terms of building materials divided into groups upon building which aerated concrete and reinforced concrete were used. The third highest value of $\mathrm{PEI}$ was reached in surface materials (60214.8 MJ)

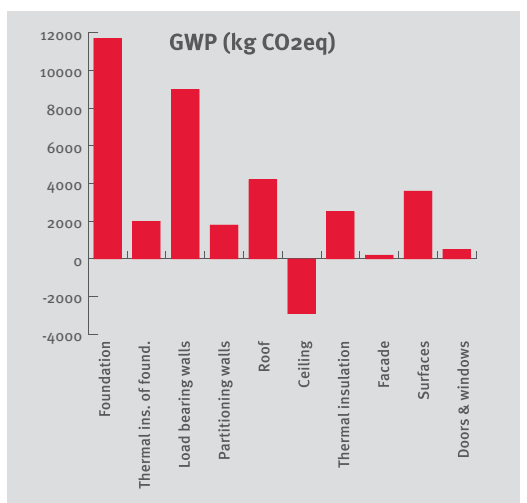

Figure 6: Primary energy intensity in particular structures (MJ)

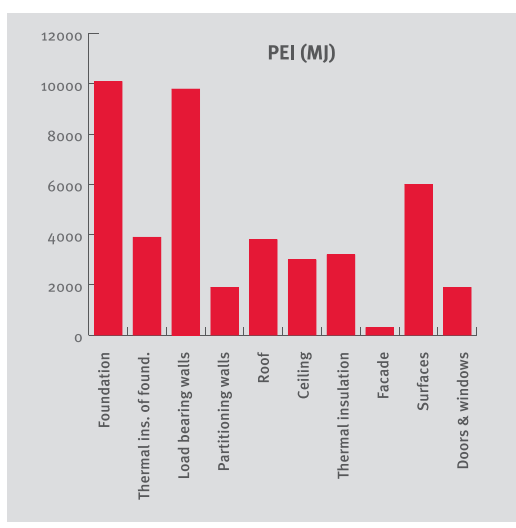

Figure 7: Global warming potential in particular structures ( $\mathrm{kg} \mathrm{CO} 2 \mathrm{eq})$

The highest amount of $\mathrm{CO}_{2}$ emissions (fig. 7) was recorded in foundations (11508.7 kg CO eq), followed with load bearing walls (9325.3 $\mathrm{kg} \mathrm{CO}$ eq) and ceiling made of reinforced concrete $(5027.1 \mathrm{~kg} \mathrm{CO}$ eq). On the other hand, the negative contribution to global warming was registered for construction of roof due to intensive use of natural renewable material - wood (Gustavsson, et al., 2010). A life cycle analysis of a building material should consist of evaluation of every phase of its existence, however usually system boundaries are set to "cradle to site", so a negative amount of $\mathrm{CO}_{2}$ emissions can be achieved if a phase of growth of natural material, during which a substantial quantity of $\mathrm{CO}_{2}$ is absorbed, is taken into consideration. The negative 


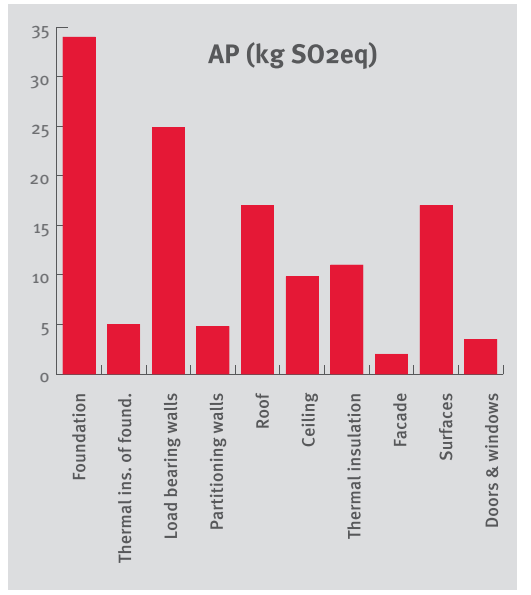

Figure 8: Acidification potential in particular structures $\left(\mathrm{kg} \mathrm{SO}_{2}\right.$ eq)

GWP for this construction was reached in spite of the fact that a relatively large amount of concrete roof tiles was used. The highest contribution to acidification (fig. 8) was calculated for foundations (34.2 kg SO eq), followed with load bearing walls ( $25.0 \mathrm{~kg} \mathrm{SO}$ eq) and the third highest AP was calculated for surfaces (17.4 kg SO 2 eq).

As seen from results above, the most negative environmental impact was recorded for materials of foundations (plain concrete, reinforced concrete) and for material used for masonry of vertical walls (aerated concrete). The main reason is the relatively large amount of relatively heavy materials used for these components. On the other hand, by a precise selection of certain kind of building materials it is possible to reduce the negative impact on environment (e.g. the use of wood in the roof led to negative amount of $\mathrm{CO}_{2}$ emissions).

\section{Conclusion}

These days, decisions of designers, architects or developers are still oriented on selection of buildings materials based on their technical properties and price. However, the choice of building materials represents an important factor in the overall influence on environment. In spite of the fact that during the operational phase of building life cycle the largest emissions of greenhouse gasses and acidifying gasses are produced, as well as the principal energy consumption is recorded, a selection of appropriate building materials may lead overall reduction of the negative environmental impact of building industry. The use of natural materials, such as natural materials (e.g. wood in roof) may lead to a negative contribution to global warming. The use of natural materials may be therefore one possible way to retain sustainability.

To achieve energy efficiency and low emissive build up first of all it is necessary to analyze the material composition of current buildings. Results of case study presented only particular results of environmental assessment of one building, and are therefore difficult to be interpreted. However, cognition of environmental impact of building materials used for the building construction may involve a further optimization of constructional design with different more suitable materials, and should be therefore an important phase of building design.

\section{Acknowledgements}

The research has been carried out within the project NFP 26220120018 and NFP 26220120037 Centre of excellent integrated research of the progressive building structures, materials and technologies, supported from the European Union Structural funds.

\section{References}

Berge, B. (2009), The Ecology of Building

Materials, Elsevier, Architectural Press, Oxford.

Eštoková, A. (2008), “Environmental certification of building materials in Slovak republic", In: Visnik Nacionalnogo universitetu L'vivska politechnika. Vol. 627, p. 219-222.

Gustavsson, L., Joelsson, A. and Sathre, R. (2010), “Life cycle primary energy use and carbon emission of an eight-storey wood-framed apartment building", In: Energy and Buildings, Vol. 42, pp. 230-242.

Hodkova, J. (2009), “Environmental Parameters of Building Materials and Structures - Data Uncertainties", In: Juniorstav 2009, Brno, Czech republic, pp.1-8.

Khasreen, M. M., Banfill, P. F. G. and Menzies, G. F. (2009), “Life-Cycle Assessment and the Environmental Impact of Buildings: A Review", Sustainability, Vol. 1, No. 3, pp. 674-701. Kierulf, B. (2008), “Ecological Build-up of Energy Passive Houses” (in Slovak), In: Passive houses 2008, Passive house center, Brno, Czech republic.

Porhincak, M., Estokova, A. and Vilcekova, S. (2010), “Comparison of Environmental Impact of Building Materials of Three Residential Buildings", working paper [Pollack Periodica, DOI: 10.1556/ Pollack.6.2011.1.x, Vol. 6, No. 1].

Tomkova, J. (2009), "Family House - New Building”, [Blueprint] (Civil Engineering Faculty, Košice, Slovakia).

Vonka, M. (2010), “Environmental impact assessment of buildings, Accompanying script for training of auditors of SBToolCZ" (in Czech), CVUT, Civil Engineering Faculty, Prague, Czech republic.

Waltjen, T. (2009), “PassivhausBauteilkatalog. Details for Passive Houses: Okologisch bewertete Konstruktionen. A Catalogue of Ecologically Rated Constructions" (in English \& German), Springer, Vienna. 